\title{
Studi Religiusitas, Budaya Sunda, dan Perilaku Moral pada Masyarakat Kabupaten Bandung
}

\author{
Ujam Jaenudin $^{1}$, Tahrir ${ }^{2}$ \\ ${ }^{1,2}$ UIN Sunan Gunung Djati, Jl. A. H. Nasution No.105 Cibiru - Bandung \\ 2 e-mail: tahrir@uinsgd.ac.id
}

\begin{tabular}{llll}
\hline Abstract / Abstrak & & Keywords / Kata kunci \\
\cline { 1 - 3 } $\begin{array}{l}\text { This research was based on the phenomenon of religiosity and the application of } \\
\text { Sundanese cultural values in Bandung. The purpose of this study is to determine } \\
\text { the effect of Sundanese resilience and culture on moral behavior. The design of } \\
\text { this study uses a causality design that aims to determine how much influence one } \\
\text { variable has on another. The total sample were 100 villagers. The data was } \\
\text { collected using a set of questionnaire of religiosity, Sundanese culture, and moral } \\
\text { behaviour, with Likert model. Hypothesis was tested using regression. The }\end{array}$ & & $\begin{array}{l}\text { Religiousta Culture } \\
\text { Morality }\end{array}$ \\
findings show that religiosity and Sundanese culture have positive and significant \\
effect on moral behavior.
\end{tabular}

\section{Pendahuluan}

Kabupaten Bandung merupakan salah satu kabupaten di Provinsi Jawa Barat dengan pusat pemerintahannya berkedudukan di Soreang. Secara geografis Kabupaten Bandung berada diantara beberapa kabupaten dan kota. Tepatnya disebelah utara berbatasan dengan Kabupaten Bandung Barat dan Kota Bandung; bagian Timur berbatasan dengan Kabupaten Sumedang dan Kabupaten Garut; sementara sebelah selatan berbatasan dengan Kabupaten Cianjur dan sebelah Barat berbatasan dengan Kota Cimahi. Kabupaten Bandung memiliki 31 kecamatan, 266 Desa serta 9 Kelurahan. Adapun jumlah penduduknya sebanyak 2.943.283 jiwa.

Untuk terus meningkatkan kinerja pembangunan maka Pemerintah Kabupaten Bandung telah menetapkan rencana pembangunan melalui Rencana Kerja Pemerintah
Daerah (RKPD). Berdasarkan dari hasil penilaian kinerja diketahui bahwa kinerja Pemerintah Kabupaten bandung terus meningkat setiap tahun. Hal ini berarti telah sesuai dengan visi yang telah dirumuskan secara bersama oleh Pemerintah Kabupaten Bandung yaitu: Terwujudnya masyarakat kabupaten bandung yang repeh, rapih, kertaraharja melalui akselerasi pembangunan partisipatif yang berbasis religius, kultural, dan berwawasan lingkungan dengan berorientasi pada peningkatan kinerja pembangunan desa.

Repeh Rapih Kertaraharja maksudnya adalah suatu kondisi yang menggambarkan masyarakat Kabupaten Bandung hidup dalam keadaan aman, sejahtera, dan senantiasa dilindungi, dibimbing dan memperoleh rahmat dari Allah SWT.

Akselerasi Pembangunan berarti segala upaya yang dilakukan oleh pemerintah 
Kabupaten Bandung beserta seluruh unsur dalam pemerintah dan segenap komponen masyarakat untuk menciptakan pembangunan yang lebih efektif dan efisien, sehingga hasilnya dapat dirasakan langsung oleh seluruh komponen masyarakat Kabupaten Bandung.

Partisipatif maksudnya adalah dalam proses pembangunan disegala bidang pemerintah Kabupaten Bandung senantiasa melibatkan seluruh komponen masyarakat. Dalam pengertian lain masyarakat diberi kesempatan seluas-luasnya untuk berpartisipasi dalam menyukseskan pembangunan.

Sedangkan religius maksudnya adalah bahwa dalam proses pembangunan senantiasa dinaungi oleh nilai-nilai, norma, dan kaidah agama khususnya Islam yang diyakini dan dianut oleh mayoritas masyarakat Kabupaten Bandung. Disamping itu dalam proses pergaulan sehari-hari masyarakat Kabupaten Bandung juga harus senantiasa diwarnai oleh nilai-nilai dan semangat agama Islam.

Kultural memiliki makna bahwa nilai dan norma budaya sunda telah melekat dan menjadi identitas masyarakat Kabupaten Bandung. Disamping itu nilai-nilai dan norma-norma yang telah melekat pada masyarakat Sunda senantiasa tumbuh dan berkembang seiring dengan laju pembangunan Kabupaten Bandung. Demikian juga nilai-nilai budaya Sunda harus menjadi perekat keselarasan dan stabilitas sosial.

Sedangkan makna berwawasan atau berorientasi pada lingkungan adalah seluruh komponen individu di Kabupaten bandung harus senantiasa memiliki perhatian dan kepekaan yang tinggi terhadap kestabilan alam dan kelestarian lingkungan dalam rangka untuk menciptakan kehidupan yang lebih sejahtera dan lebih berkualitas baik untuk saat ini maupun untuk masa generasi berikutnya. Dengan daya dukung sumber daya manusia yang berkualitas maka diharapkan seluruh proses pembangunan di Kabupaten Bandung akan berjalan dengan lancar dan berkelanjutan.

Kampung Mahmud adalah salah satu kampung yang ada di Kabupaten Bandung yang masih sangat menjaga nilai-nilai budaya sunda dan nilai agama terutama agama Islam. Menurut peneliti Kampung Mahmud yang berada di Kecamatan Margaasih sangat menggambarkan visi dan misi Kabupaten Bandung. Berdasarkan hasil studi pendahuluan peneliti menemukan bahwa masyarakat di Kampung Mahmud sangat religius dan masih menjaga nilai-nilai budaya sunda.

Berdasarkan hasil wawancara pendahuluan diketahui bahwa dalam beragama masyarakat Kampung Mahmud lebih menekankan pada apa yang harus dipercayai daripada apa yang harus dikerjakan. Tingkat religiusitas juga tergambar pada keinginan yang sangat tinggi pada masyarakatnya untuk dapat melaksanakan rukun iman yang ke lima yaitu ibadah haji dengan cara mengorbankan harta yang dimiliki.

Kehidupan religius masyarakat Kampung Mahmud juga dapat diamati dengan banyaknya kegiatan yang bersifat meriah setiap ada harihari besar Islam. Seperti peringatan maulid Nabi, peringatan Muharam, penyambutan bulan Ramadhan, dan juga hari-hari besar Islam yang lainnya. Pada acara hari-hari besar masyarakat Kampung Mahmud selalu menyediakan makanan untuk dibagikan kepada tetangga.

Disisi lain masyarakat Kampung Mahmud juga masih sangat menjaga nilai-nilai budaya Sunda, seperti rumah panggung yang keberadaannya masih lestari sampai saat ini, kebiasaan yang juga masih dilakukan adalah jika akan melakukan segala sesuatu maka harus ditawasulkan ke para karuhun atau para leluhur mereka. Mereka percaya jika bentuk rumah, bahan rumah, dan cara membangun rumah serta dalam melaksanakan sesuatu tidak ditawasulkan ke para leluhur maka akan tertimpa petaka.

Masyarakat Kampung Mahmud juga masih memiliki keyakinan yang sangat kuat terhadap istilah tabu, cadu, atau pacaduan yang harus dipatuhi oleh seluruh masyarakat. Dan jika ada warga yang melanggap pacaduan maka harus dihukum oleh ketua adat yang sangat dihormati.

Religiusitas adalah suatu konsep yang sudah sangat populer yang berasal dari bahasa latin yaitu relegare, dalam bahasa Indonesia relegere bermakna mengikat secara erat atau ikatan kebersamaan (Mansen, dalam Kaye \& 
Raghavan, 2000). Religiusitas adalah ekspresi spiritual individu dalam mengamalkan keagamaannya yang berkaitan dengan sistem keyakinan, nilai, hukum yang berlaku dan ritual (Kaye \& Raghavan, 2000). Religiusitas menggambarkan bagaimana cara-cara individu mengabdi kepada Tuhan yang yang didasarkan dari kitab suci.

Religiusitas adalah aspek yang telah tertanan secara mendalam dan dihayati oleh individu di dalam hati, getaran hati dan sikap personal (Mangunwija, 1986). Sementara menurut Glock dan Stark (Dister, 1988) religiusitas adalah sikap keberagamaan yang dimiliki individu yang telah terinternalisasi secara mendalam dan menjadi bagian tak terpisahkan dari dirinya.

Rahmat (2001) mendefinisikan bahwa religiusitas adalah suatu keadaan dalam diri seseorang yang mendorong untuk berperilaku sesuai dengan kadar ketaatannya terhadap agamanya. Religiusitas merupakan pengetahuan, keyakinan dan perilaku yang bersumber langsung atau tidak langsung kepada Nash.

Berdasarkan pada definisi Glock dan Strak (dalam Rahmat, 2001) maka peneliti merumuskan pengertian bahwa relegiusitas adalah komitmen seseorang terhadap agamanya dalam bentuk pengetahuan, keyakinan, peribadatan, yang termanifestasi dalam perilaku dan ucapannya. Religiusitas individu sering diartikan seberapa dalam pengetahuanpengetahuan agamanya, seberapa kuat keyakinan terhadap nilai-nilai dan dogmadogma agama, seberapa intens melaksanakan ibadah yang dianjurkan oleh agama dan seberapa dalam penghayatan terhadap nilai-nilai agama yang dianutnya.

Glock (Rahmat, 2003) membagi aspek religiusitas menjadi lima aspek yaitu: ideologi, peribadatan, penghayatan, pengetahuan, pengamalan.

Aspek ideologi atau keyakinan berkaitan dengan kuatnya keyakinan dan kepercayaan seseorang terhadap ajaran-ajaran agama terutama yang bersifat fundamental dan dogmatik. Agama selalu menuntut umatnya untuk percaya mempertahankan kepercayaan terhadap nilai-nilai, ajaran, dan ritual keagamaan sebagai bukti atas ketundukannya terhadap agama. Namun demikian masingmasing agama memiliki tuntutan yang berbeda berkaitan dengan ruang lingkup keyakinannya.

Seperti contoh dalam agama Islam, agama Islam menuntut umatnya untuk memiliki keyakinan bahwa Tuhan adalah Esa. PengEsaan Tuhan dalam Islam menjadi esensi dari ke Islaman seseorang. Peng-Esaan Tuhan adalah ruh dan inti yang menjadi ciri apakah seseorang beragama Islam atau tidak. Karena Islam menuntut umatnya untuk meng-Esakan Tuhan maka Islam disebut sebagai agama monoteisme. Yaitu agama yang memiliki keyakinan bahwa Tuhan hanya satu dan tidak ada yang lainnya.

Aspek peribadatan, berkaitan dengan rutinitas pemujaan seorang hamba terhadap Tuhan-nya, sebagai bukti mahwa manusia memiliki komitmen yang tinggi terhadap agama dan tunduk terhadap segala aturannya. Praktikpraktik keagamaan bagi agama apapun sepenuhnya telah diajarkan oleh masing-masing agama untuk dilaksanakan oleh umat agama sebagai bukti akan ketaatannya. Glock dan Stark (dalam Rahmat, 2003) membagi aspek peribadatan menjadi dua kelas yaitu:

a. Ritual adalah aktivitas-aktivitas rutin sebagai tuntutan dari agama terhadap umatnya, tindakan tersebut ada yang bersifat formal dan praktik-praktik suci yang harus dilaksanakan oleh setiap umatnya. Dampak dari pelaksanaan ritual keagamaan biasanya dapat dirasakan oleh umat beragama dalam bentuk ketenangan jiwa. Hal ini terjadi karena dalam praktikpraktik ritual keagamaan umat beragama akan mendapatkan momen di mana seseorang bisa berkonsentrasi, meditasi, dan kontemplasi sehingga jiwa manusia bisa terasah dan akan bening hatinya.

Praktik-praktik ritual bagi umat beragama sebenarnya adalah momen untuk bisa dijadikan menusia untuk mendekatkan diri terhadap Tuhan Yang Maha Kuasa dan menyadari bahwa dirinya lemah. Oleh karena itu manusia membutuhkan meka- 
nisme untuk mengatasi kelemahan dan keterbatasannya dengan mengharap dan momohon bantuan kepada Sang Pencipta melalui praktik-praktik ibadah.

b. Ketaatan adalah komitmen yang diberikan oleh umat beragama terhadap agamanya dalam bentuk pelaksanaan ibadah-ibadah sesuai dengan yang dianjurkan oleh agama. Komitmen dalam pelaksanaan ibadahibadah adalah sesuatu yang sangat diharapkan untuk dilaksanakan sebagai bentuk tanggung jawab dan konsekuensi telah menyatakan dirinya beragama.

Aspek pengalaman, aspek ini berkaitan dengan kedalaman perasaan seseorang terhadap pengalaman-pengalaman religiusitasnya yang memiliki makna bagi dirinya. Aspek ini melibatkan atribut psikologis yang sangat mendalam yaitu emosional dan sentimental pada saat pelaksanaan ajaran agama ataupun setelah pelaksanaan ajaran-ajaran agama. Aspek perasaan keagamaan terbagi menjadi empat tingkat yakni: Konfirmatif adalah perasaan akan kehadiran Tuhan pada saat melaksanakan peribadatan. Responsif adalah perasaan bahwa Tuhan dapat menjawab apa yang menjadi keinginan dan keluhan hambanya. Eskotik adalah perasaan bahwa manusia sebagai hamba dapat merasakan keakraban hubungan dan penuh cinta dengan Tuhan. Partisipatif adalah perasaan bahwa manusia sebagai hamba Tuhan merasakan betul bahwa ia dapat menjadi kekasih Wali Tuhan dalam melakukan perintahperintah Tuhan.

Wujud nyata aspek pengalaman adalah perasaan bersyukur kepada Allah, perasaan khusyuk pada saat melaksanakan ibadah dan berdoa, perasaan bergetar dan merinding ketika mendengar ayat-ayat suci dibacakan, merasa syahdu melihat ka'bah atau tempat-tempat suci agama, dan perasaan mendapatkan pertolongan dari Tuhan.

Aspek pengetahuan, aspek ini berkaitan dengan tingkat pengetahuan dan pemahaman umat beragama terhadap nilai-nilai dan ajaran tentang agama, khususnya ajaran esensial agamanya. Dalam agama Islam aspek ini berhubungan dengan pemahaman terhadap kandungan alquran, rukun Islam, rukun Iman, hukum Islam, dan sejarah Islam.

Aspek pengetahuan religiusitas bisa diperoleh melalui berbagai cara : membaca buku-buku keagamaan, mendatangi tempattempat pendidikan keagamaan, diskusi, dan lain-lain. Pemahaman manusia tentang ajaranajaran agamanya dapat dicapai melalui aktivitas rasional empiris yaitu dengan bergaul langsung dengan masyarakat atau umat beragama, bisa juga melalui tekstual-normatif yaitu proses pengkajian terhadap ajaran-ajaran agama yang tertulis dalam buku-buku agama maupun kitab sucinya. Proses menemukan pemahaman dan pemaknaan terhadap ajaran-ajaran agama yang dilakukan oleh manusia dapat menimbulkan praktik ritual-ritual keagamaan dan dalam kehidupan sehari-hari manusia sebagai bermasyarakat.

Proses pembangunan Pemerintah Kabupaten Bandung melalui akselerasi pembangunan partisipatif yang berbasis religious menjadi fenomena yang menarik untuk diteliti. Pemerintah Kabupaten Bandung mengungkapkan indikator religiusitas yang tinggi pada masyarakatnya jika telah mentaati peraturan-peraturan yang telah diterapkan pemerintah, berperilaku sopan dan santun, menghargai terhadap sesama, menjaga kelestarian alam, menjaga kebersihan lingkungan dll.

Indikator perilaku ini benar-benar dapat terwujud jika masyarakatnya benar-benar memahami dan menghayati seluruh ajaran agamanya. Karena pada kenyataannya ajaranajaran agama sangat selaras dengan kehidupan manusia dan juga ajaran agama memberikan aturan dan bimbingan yang sangat maksimal terhadap semua umatnya dalam menjalani kehidupan di dunia.

Menurut Ekadjati (1995) Sunda adalah suatu wilayah yang merupakan daerah bekas Kerajaan Sunda Pajajaran, pada kemudian hari berdirilah kerajaan-kerajaan kecil yaitu kerajaan Sumedang Larang, kerajaan Banten, kerajaan Cirebon, dan dan kerajaan Galuh. Kerajaan Sumedang Larang dan Kerajaan Galuh selanjutnya bergabung menjadi satu wilayah yaitu Priangan. Dalam perkembangan selanjutnya, 
wilayah Priangan terkenal sebagai pusat tanah Sunda dan kebudayaan Sunda.

Namun, jika kata Sunda dipahami sebagai sebuah etnisitas atau wilayah, maka permasalahannya tidak sesulit mendefinisikan Sunda sebagai orang Sunda. Orang Sunda dengan mudah bisa disebut dengan individu yang mengaku dan merasa dirinya orang Sunda dan demikian juga diakui orang sunda oleh orang lain (Warnaen dkk., 1987: 1).

Bersandarkan pada pengertian tersebut di atas maka setidaknya terdapat dua pengertian esensial untuk mengidentifikasi seseorang sebagai urang Sunda dan bukan urang Sunda. Pengertian yang pertama adalah merujuk pada keturunan atau pertalian darah. Oleh karena itu, orang disebut sebagai urang Sunda jika ayah dan ibunya asli orang sunda, tidak peduli dimana ia dilahirkan, berada, dan dibesarkan oleh orang tuanya.

Sedangkan kriteria yang kedua adalah didasarkan pada unsur budaya. Dimana orang diidentifikasi sebagai urang Sunda apabila ia dilahirkan dan dibesarkan disuatu daerah yang senantiasa menerapkan budaya Sunda, nilainilai budaya Sunda, dan norma-norma Sunda dalam kehidupan sehari-harinya. Pada kriteria yang kedua ini, poin yang paling esensial adalah tempat dimana seseorang sehari-harinya tinggal, dan norma-norma budaya yang digunakan dalam kehidupan sehari-harinya.

Budaya Sunda tumbuh, berkembang, dan hidup bersama dengan pola kehidupan masyarakat Sunda. Masyarakat umum mengenal budaya Sunda sebagai budaya yang sangat menjunjung tinggi sopan santun dan budaya yang sangat menghormati dan menghargai kehidupan bermasyarakat yang damai dan tentram.

Dalam budaya Sunda ada beberapa nilai yang sangat dijunjung tinggi untuk dalam rangka menuju keutamaan hidup yaitu cageur, bageur, bener, singer, dan pinter.

Berdasarkan pada fenomena tentang religiusitas dan pelaksanaan budaya-budaya sunda yang sangat kental dimasyarakat Kampung Mahmud seperti telah dikemukakan di atas maka peneliti merasa sangat tertarik untuk melakukan penelitian tengan religiusitas, budaya sunda, dan moralitas pada masyarakat Kampung Mahmud. Kebaruan penelitian ini adalah adanya kajian budaya sunda yang dikaitkan dengan nilai-nilai moral. Selama ini penelitian tentang budaya Sunda sangat jarang dilakukan terutama yang menggunakan pendekatan kuantitatif.

\section{Metode}

Pada penelitian ini peneliti menggunakan pendekatan analisis deskriptif, yakni jenis analisis yang berusaha untuk menggambarkan fenomena-fenomena sosial, menerangkan hubungan antar variabel, menguji hipotesis, menaksir parameter dan menemukan makna serta konsekuensinya dari suatu masalah yang akan dipecahkan (Nazir, 1988:64).

Adapun metode yang digunakan dalam penelitian ini adalah metode korelasi kausalitas. Metode korealsi kausalitas adalah suatu metode yang ingin mengetahui hubungan sebab akibat antara variabel bebas dengan variabel terikat. Selanjutnya untuk menganalisis data hasil penelitian digunakan metoda analisis regresi berganda.

Pada penelitian ini peneliti melibatkan dua variabel yakni variabel bebas $(\mathrm{X})$ dan variabel terikat (Y):

Variabel bebas dengan notasi variabel $\mathrm{X}$, yaitu suatu variabel yang ingin dilihat akibatnya terhadap variabel lain. Variabel $\mathrm{X}$ yang dimaksud adalah religiusitas dan budaya Sunda. Sedangkan variabel terikat (dependent variable) dengan notasi variabel $\mathrm{Y}$, adalah perilaku moral masyarakat Kampung Mahmud Desa Mekarrahayu Kecamatan Margaasih Kabupaten Bandung. Data yang diperoleh dari penelitian ini berbentuk angka atau sering disebut data kuantitatif.

\section{Hasil}

Analisis data dalam penelitian ini menggunakan uji regresi berganda dengan bantuan software SPSS versi 22. Berdasarkan hasil uji statistik dengan analisis regresi terhadap variabel $\mathrm{X}$ yaitu Religiusitas dan 
variabel Y yaitu Perilaku Moral Masyarakat diperoleh data bahwa nilai $\mathrm{R}$ sebesar .507. Ini berarti religiusitas berkorelasi dengan perilaku moral, dan tingkat korelasi tersebut berada pada kategori sedang. Sedangkan nilai R Square sebesar .257, artinya variabel religiusitas memiliki pengaruh sebesar $25.7 \%$ terhadap Perilaku Moral dan $74.3 \%$ lainnya dipengaruhi oleh faktor-faktor lain diluar variabel variabel lain.

Sedangkan $\mathrm{F}_{\text {hitung }}=16.63866$ dan $\mathrm{p}_{\text {value }}=$ $.000<\alpha=.05$, maka dapat disimpulkan bahwa model persamaan regresi pada penelitian ini adalah signifikan, dengan demikian model regresi linier memenuhi kriteria linieritas.

Selanjutnya diketahui hasil uji regresi menunjukkan persamaan regresi sebagai berikut:

$$
\begin{aligned}
& \mathrm{Y}=\mathrm{a}+\mathrm{bX} \\
& \mathrm{Y}=15.11277+0.566039 \mathrm{X}
\end{aligned}
$$

Ini menunjukan bahwa konstanta dari penelitian ini adalah sebesar 15.112; artinya jika nilai religiusitas $(\mathrm{X})$ sebesar 0 , maka nilai Perilaku Moral (Y) adalah positif sebesar 15,112. Koefisien regresi variabel religiusitas (X) sebesar .566; artinya jika harga mengalami kenaikan Rp.1, maka perilaku moral masyarakat (Y) akan mengalami peningkatan sebesar .566. Koefisien bernilai positif artinya terjadi hubungan positif antara religiusitas dengan perilaku moral masyarakat, semakin tinggi religiusitas maka semakin meningkatkan perilaku moral masyarakat.

Pengolahan data hasil penelitian menggunakan bantuan program SPSS versi 22 . Berdasarkan hasil uji statistik dengan analisis regresi terhadap variabel $X$ yaitu Budaya Sunda dan variabel Y yaitu Perilaku Moral Masyarakat diperoleh data bahwa nilai $\mathrm{R}$ adalah .782 . Hal ini menunjukkan hubungan antara budaya sunda dan perilaku moral ada hubungan dengan kategori tinggi. Sedangkan nilai R Square atau koefisien determinasi (KD) yang menunjukkan .612 variabel budaya sunda memiliki pengaruh sebesar $61.2 \%$ terhadap Perilaku Moral Masyarakat di Kampung Mahmud Desa Mekarrahayu Kecamatan Margaasih Kabupaten
Bandung dan 38.8\% lainnya dipengaruhi oleh faktor-faktor lain diluar variabel variabel lain.

Berdasarkan hasil uji anova diketahui bahwa nilai $\mathrm{F}=75.84543$ dan nilai $\mathrm{p}=.000$ lebih kecil dari $\alpha=.05$, maka dapat disimpulkan bahwa model persamaan regresi berdasarkan data penelitian adalah signifikan artinya, model regresi linier memenuhi kriteria linieritas.

Dan hasil uji koefisien regresi diketahui bahwa hasil uji regresi menunjukan persamaan regresi sebagai berikut:

$$
\begin{aligned}
& \mathrm{Y}=\mathrm{a}+\mathrm{bX} \\
& \mathrm{Y}=6.2226+.0702 \mathrm{X}
\end{aligned}
$$

Ini dapat diartikan sebagai berikut bahwa konstanta sebesar 6.226; artinya jika religiusitas (X) nilainya adalah 0, maka Perilaku Moral Masyarakat di Kampung Mahmud Desa Mekarrahayu Kecamatan Margaasih Kabupaten Bandung (Y) nilainya positif yaitu sebesar 6.226. Koefisien regresi variabel religiusitas (X) sebesar .702; artinya jika harga mengalami kenaikan Rp.1, maka perilaku moral masyarakat (Y) akan mengalami peningkatan sebesar .702. Koefisien bernilai positif artinya terjadi hubungan positif antara budaya sunda dengan perilaku moral masyarakat, semakin tinggi budaya sunda maka semakin meningkatkan perilaku moral masyarakat.

\section{Diskusi}

Berdasarkan pada hasil pengolahan data diatas diketahui bahwa religiusitas berpengaruh terhadap perilaku moral masyarakat di Kampung Mahmud Desa Mekarrahayu Kecamatan Margaasih Kabupaten Bandung dengan pengaruh sebesar 25.7\%. Demikian juga budaya Sunda juga berpengaruh terhadap perilaku moral dengan pengaruh sebesar 61.24\%. Dengan melihat pada hasil penelitian ini diketahui bahwa nilai budaya Sunda pengaruhnya terhadap perilaku moral masyarakat lebih besar dari pada religiusitas.

Tingkat religiusitas yang tinggi pada individu seharusnya tergambarkan dalam perilaku sehari-harinya, karena berdasarkan dari dimensi religiusitas yang dikemukakan oleh Glock dan Stark bahwa religiusitas butuh 
pengamalan dan peribadatan. Pada penelitian ini terbukti bahwa nilai-nilai agama yang diyakini dan diamalkan dalam kehidupan sehari-hari dapat berpengaruh terhadap kualitas moral sehari-hari.

Namun demikian pengaruhnya terhadap perilaku moral belum begitu besar karena baru mencapai $25.7 \%$. Hal ini dimungkinkan karena selama ini agama yang diyakini oleh masyarakat masih sebatas keyakinan yang belum berdampak dalam kehidupan sehari-hari. Demikian juga ritual yang selama ini dilakukan masih sebatas melaksanakan kewajiban bukan merupakan perilaku kesadaran dalam ketaatan terhadap Allah SWT sebagai sang pencipta.

Hasil penelitian ini sesuai dengan hasil penelitian Reza (2013) menemukan bahwa religiusitas berpengaruh signifikan terhadap moralitas pada siswa Madrasah Aliyah. Penelitian ini juga sesuai dengan penelitian Darajat (1989) yang menemukan bahwa moralitas tidak bisa dipisahkan dengan agama. Agama pada kenyataannya adalah mengandung banyak nilai-nilai moral yang harus diikuti oleh seluruh umatnya.

Hasil penelitian ini juga menunjukkan bahwa budaya Sunda berpengaruh signifikan terhadap moralitas. Hasil penelitian ini sesuai dengan pendapat Sucipto (1996) bahwa dalam etnik Sunda manusia senantiasa berdasarkan pada keseimbangan agama dan sosial sehingga terbentuk ajaran hidup yang melarang manusia Sunda bersikap tidak adil terhadap sesama.

Nilai-nilai budaya sunda berpengaruh lebih besar terhadap perilaku moral masyarakat di Kampung Mahmud Desa Mekarrahayu Kecamatan Margaasih Kabupaten Bandung. Hal ini terjadi karena budaya sunda telah identitas atau jati diri masyarakat sunda sehingga nilai-nilai budaya Sunda telah merasuk ke dalam sendi-sendi kehidupan.

Walaupun agama adalah bagian dari kehidupan masyarakat sunda di Kabupaten Bandung namun karena kurangnya pemahaman terhadap agama itu sendiri sehingga nilainilainya belum bisa diamalkan secara penuh. Berbeda dengan budaya Sunda yang merupakan budaya asli, budaya nenek moyang, dan budaya bawaan sehingga walaupun tidak diajarkan dengan dengan terstruktur tetap akan dilakukan dan menjadi bagian dari kehidupan masyarakat sunda terutama di Kabupaten Bandung.

Budaya Sunda tumbuh, berkembang, dan hidup bersama dengan pola kehidupan masyarakat Sunda. Masyarakat umum mengenal budaya Sunda sebagai budaya yang sangat menjunjung tinggi sopan santun dan budaya yang sangat menghormati dan menghargai kehidupan bermasyarakat yang damai dan tentram.

\section{Simpulan}

Berdasarkan dari hasil penelitian ini diketahui bahwa:

1. Religiusitas berpengaruh terhadap perilaku moral masyarakat di Kampung Mahmud Desa Mekarrahayu Kecamatan Margaasih Kabupaten Bandung.

2. Budaya Sunda berpengaruh terhadap perilaku moral masyarakat di Kampung Mahmud Desa Mekarrahayu Kecamatan Margaasih Kabupaten Bandung.

3. Budaya Sunda memiliki pengaruh yang lebih tinggi terhadap perilaku moral masyarakat di Kampung Mahmud Desa Mekarrahayu Kecamatan Margaasih Kabupaten Bandung.

\section{Saran}

Berdasarkan dari hasil penelitian ini maka saran penelitiannya adalah:

1. Pemerintah Kabupaten Bandung disarankan untuk lebih intensif lagi dalam memberi pemahaman kepada masyarakat dalam religiusitasnya

2. Pemerintah Kabupaten Bandung disarankan untuk menjelaskan pada masyarakat bahwa agama bukan hanya sekedar identitas dan ritual namun nilai-nilainya harus diamalkan dalam kehidupan seharihari agar dapat miningkatkan perilaku moralnya

3. Pemerintan Kabupaten Bandung disarankan untuk terus mendorong masyarakat dalam melestarikan budaya sunda karena 
berdasarkan penelitian bahwa budaya Sunda memiliki pengaruh yang besar dalam meningkatkan perilaku moral masyarakat

\section{Referensi}

Ancok, \& Suroso. (2001). Psikologi Islam. Yogyakarta: Pustaka Belajar.

Ahyadi, A. A. (2001). Psikologi agama, kepribadian muslim. Bandung: Sinar Baru.

Atja, \& Danasasmita, S. (1981). Sanghyang Siksakandang Karesian (Naskah Sunda Kuno). $\quad$ Bandung: Proyek Pengembangan Permuseumam Jawa Barat.

Danasasmita, S. dkk. (1987). Sewaka Darma, Sanghyang Siksakandang Karesian, Amanat Galunggung. Transkripsi dan Terjemahan. Bandung: Bagian Proyek Sundanologi

Daradjat, Z. (1989). Ilmu jiwa agama. Jakarta: Bulan Bintang.

Darsa, U. A. (1998). Sanghyang Hayu. Naskah Jawa Kuno di Sunda. Bandung: Program Pascasarjana Unpad (Tesis).

Hawari, D. (1996). Alquran ilmu kedokteran dan kesehatan jiwa. Solo: PT. Amanah Bunda Sejahtera.

Ekadjati, E. S. (2007). Nu maranggung dina sajarah Sunda. Bandung: Pusat Studi Sunda.

Ekadjati, E. S. (2014). Kebudayaan Sunda suatu pendekatan sejarah. Bandung: Pustaka Jaya.

Hadi, S. (2004). Metodologi research. Andi, Yogyakarya.

Hidayah, Z. (2015) Ensiklopedi suku bangsa di Indonesia.

Purwadi. (2007). Sejarah raja-raja Jawa: Sejarah kehidupan Kraton dan perkembangannya di Jawa. Yogyakarta: Media Abadi.

Rahmat, J. (2001). Psikologi agama. Jakarta: PT. Raja Grafindo Persada.
Reza, I. F. (2013) Hubungan antara religiusitas dengan moralitas pada remaja di Madrasah Aliyah (MA). Jurnal Humanitas, 10(2).

Rosidi, A. (2011). Prabu Siliwangi: Sejarah atau mitos. Bandung: Pikiran Rakyat.

Rosidi, A. dkk. (2000) Ensiklopedi Sunda. Jakarta: Pustaka Jaya.

Sucipto, T. dkk. 1996. Integrasi nasional dalam hubungan antarsuku bangsa dan sistem nilai budaya nasional. Bandung: Pelita.

Sudjana. (1992). Metode statistik. Bandung: Tarsito. 